https://nv.nltu.edu.ua

Article received 10.12.2019 p.

Article accepted 27.02.2020 p.

$@ \bowtie$ Correspondence author

UDK 635.925(477-25)

H. V. Pantsyreva

apantsyreva@ukr.net

В. М. Прокопчук, І. М. Дідур, Г. В. Панцирева

Вінницький національний аграрний університет, м. Вінниця, Украйна

\title{
ПЕРСПЕКТИВИ ВИКОРИСТАННЯ РАЕОNІА Ц. У БОТАНІЧНОМУ САДУ "ПОДІЛЛЯ" ВІННИЦЬКОГО НАЦІОНАЛЬНОГО АГРАРНОГО УНІВЕРСИТЕТУ
}

Наведено результати дослідження перспективності вирощування 32 культиварів Paеопіa L. в умовах Ботанічного саду "Поділля" Вінницького національного аграрного університету. Подано літературний аналіз наукових джерел 3 порівнянням світового досвіду вирощування півоній та використання їх у ландшафтному дизайні. Наведено систематизовану та узагальнену інформацію про особливості культивування сортів і гібридів світової та української селекції, визначено найперспективніші примірники для вирощування на базі Ботанічного саду "Поділля" ВНАУ. Проведено економічну оцінку перспективності вирощування сортів та гібридів Paeonia L. на архітерно-експозиційній ділянці BНАУ. У процесі дослідження визначено актуальність використання досліджуваних представників Paеonia L. для озеленення міст, селищ, приватних будинків для покращення естетичного сприйняття проектованих об'єктів. Порівняння отриманих результатів 3 характеристикою сортів, представленою оригінатором, показали збіг сортових ознак за всіма показниками. Проаналізовано економічну доцільність вирощування саме цих представників флори для подальшої реалізації продукції на ринку та визначено напрямки використання півоній. Доведено, що в умовах Поділля досліджувані культивари мають цінність об'єктів для збільшення сортименту багаторічних квітниково-декоративних рослин, їх використовують для поліпшення стану садів та парків України. Встановлено, що поряд 3 високими декоративними якостями культурі півонії мають широкі перспективи використання. Види роду Paeonia L. мають вагому значущість для декоративного садівництва, зокрема, квітникарства - для поповнення колекцій квітниково-декоративних рослин України. Визначено перспективи інтродукції культури півонії завдяки природним можливостям трав'яних видів, адаптаційній здатності до зміни життєвої форми та сукупності високих якісних ознак. Отже, дослідження видів роду Paeonia L. для квітникарства дасть змогу розширити сортимент квітниково-декоративних рослин та збагатити культивовану флору зони Поділля та України. Результати експериментальних досліджень будуть використані для збагачення колекції трав'яних видів півоній на базі архітектурно-експозиційної ділянки ВНАУ та практичної діяльності студентів спеціальності 206 "Садово-паркове господарство", а також науково-педагогічних працівників.

Ключові слова: Paeonia L.; культивар; варіанти використання; зона вирощування; проект; економічна ефективність.

Вступ. Квіткові багаторічники стають дедалі популярнішими в сучасному ландшафтному дизайні. Серед усього асортименту квітково-декоративних рослин до найбільш перспективних для використання в озелененні територій належить рід Paeonia L. Представники роду Paeonia L. чудово підходять як для сучасного екостилю, так і для суворого регулярного, патіо-півонії можуть використовуватися для озеленення терас, балконів, лоджій, веранд. Деревовидні півонії можуть використовуватись яскравими акцентами на фоні газону чи кори. Трав'яні півонії підходять для використання на клумбах безперервного цвітіння, рокаріях, бордюрах, рабатках, масивах, моносадах, ароматних садах, підходять для використання майже у всіх відомих ландшафтних стилях, використовуються на зріз, є перспективними для вигонки $[6,10]$.

В умовах архітектурно-експозиційної ділянки Ботанічного саду "Поділля" Вінницького національного аг- рарного університету представлені культивари трав'яних видів півонії, зокрема, молочноквіткової та вузьколистої [5]. Визначення перспектив варіантів використання допоможе значно розширити використання культури півонії в декоративному садівництві та збагатити культивовану флору зони Поділля та України загалом.

Об'єкт дослідження - квітково-декоративні рослини роду Paeonia L.

Предмет дослідження - методи і засоби використання рослин роду Paeonia L. у Ботанічному саду "Поділля".

Мета дослідження полягає у визначенні варіантів використання трав'яних видів півонії в умовах Ботанічного саду "Поділля". Згідно з зазначеною метою, основним завданням дослідження було виявлення найперспективніших сортів/гібридів для створення садових композицій з використанням півоній та подальше спостереження за цими рослинами.

\section{Інформація про авторів:}

Прокопчук Валентина Мар'янівна, канд. біол. наук, доцент, завідувач кафедри лісового, садово-паркового господарства, садівництва та виноградарства. Email: prokopchuk@vsau.vin.ua

Дідур Ігор Миколайович, канд. с.-г. наук, доцент, декан факультету агрономії та лісівництва. Email: didurigor@gmail.com

Панцирева Ганна Віталіївна, канд. с.-г. наук, ст. викладач, кафедра садово-паркового господарства, садівництва та виноградарства. Email: apantsyreva@ukr.net; https://orcid.org/0000-0002-0539-5211

Цитування за Дсту: Прокопчук В. М., Дідур І. М., Панцирева Г. В. Перспективи використання Рaеonia L. у Ботанічному саду "Поділля" Вінницького національного аграрного університету. Науковий вісник НЛтУ України. 2020, т. 30, № 1. С. 39-44.

Citation APA: Procopchuk, V. M., Didur, I. M., \& Pantsyreva, H. V. (2020). The prospects of use Paeonia L. in the Botanical Garden "Podillya" Vinnytsia National Agrarian University. Scientific Bulletin of UNFU, 30(1), 39-44. https://doi.org/10.36930/40300106 
Наукову новизну отриманих результатів полягає в тому, що вперше наведено систематизовану та узагальнену інформацію про особливості культивування сортів і гібридів світової та української селекції, визначено найперспективніші примірники рослин роду Paeonia L. для вирощування на базі Ботанічного саду "Поділля" BНАУ.

Практичне значення одержаних результатів полягає в тому, що проведені дослідження рослин роду Paeonia L. для квітникарства дасть змогу розширити сортимент квітниково-декоративних рослин та збагатити культивовану флору зони Поділля та України. Результати експериментальних досліджень будуть використані для збагачення колекції трав'яних видів півоній на базі архітектурно-експозиційної ділянки ВНАУ та практичної діяльності студентів спеціальності 206 "Садово-паркове господарство", а також науково-педагогічних працівників.

Аналіз досліджень і публікацій. У нашій державі селекцію півонії розпочали у 1950 -х роках вчені-квітникарі А. А. Сосновець і I. С. Краснова [4]. На сьогодні культури півонії селекціонує Київський ботанічний сад iм. Гришка. Учений-селекціонер В. Ф. Горобець створив багато сортів та гібридів, таких, як: Ірокез, Героям небесної сотні, Червоний Оксамит, Чебурашка, Червоні Вітрила, Офелія, Ювілей Києва, Скарбниця і багато інших, які є основою для української селекції $[2,3]$. Найпоширенішими у світовому декоративному садівництві є Paeonia lactiflora Pall. - це багаторічні рослини трав'яного типу, які належать до родини Paeoniaceae. У світі налічується близько 5000 культиварів $[1,8,11]$.

Представники роду Paeonia L. часто застосовують в озелененні присадибних ділянок та громадських місць. 3 цією метою використовують як трав'яні представники, так і деревовидні та іто-групи. Завдяки селекційній роботі українських і світових науковців, з'являються все нові цікаві та перспективні сорти [7]. Проте в озелененні Поділля використовують переважно півонію молочноквіткову (Paeonia lactiflora L.) та іiі гібриди. Це пов'язано 3 відсутністю науково обгрунтованої інформації про еколого-біологічні особливості, здатність до адаптації, способи вирощування та розмноження та варіанти їх використання $[4,5,12]$. Проблеми вирощування Paeonia L. в умовах Вінниччини, а також декоративні, морфометричні та біологічні особливості представників роду, потрібно вивчати на науковому рівні з подальшим дослідженням перспективності та поповненням асортименту популярних сортів Вінницької обл. та всієї України.

На території Ботанічного саду "Поділля" ВНАУ представлені сорти та гібриди трав'яних видів півонії. Трав'яні півонії - одні 3 найбільш легко вирощуваних та витривалих багаторічних рослин на сьогодні. Довговічні і надійні, вони можуть легко зростати до 100-120 років. Серед трав'яних багаторічників, рослини здатні виробляти щорічний приріст стебла впродовж весни та влітку, відмираючи пізно восени і залишаючись у спокої зимовий сезон $[1,9,11]$.

Матеріал та методи дослідження. Матеріалом для проведення дослідження є культивари Paeonia L. української та світової селекції (рис. 1).

Дослідження проводили впродовж 2018-2019 рр. на базі архітектурно-експозиційної ділянки Ботанічного саду "Поділля" Вінницького національного аграрного університету. Грунтово-кліматичні умови зони дослідження сприятливі для вирощування досліджуваного виду Paeonia L.

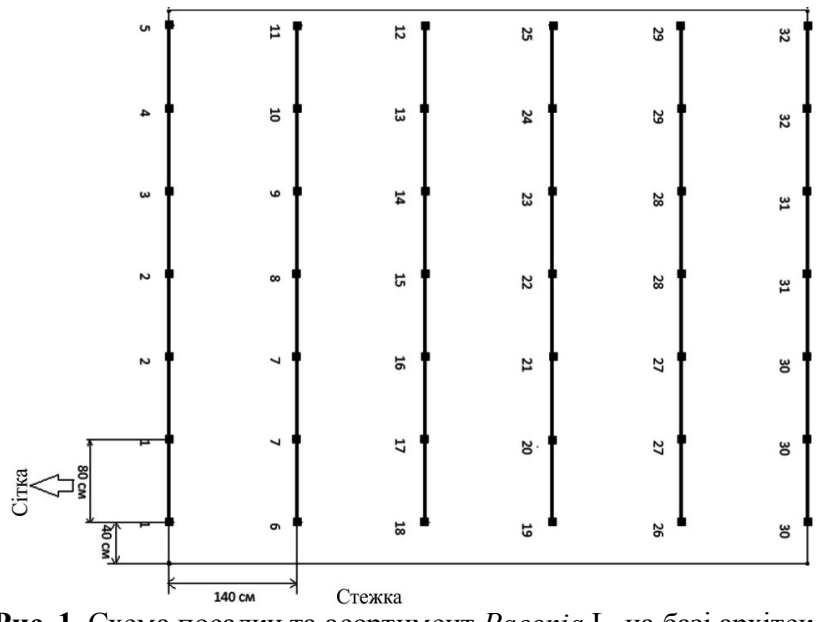

Рис. 1. Схема посадки та асортимент Paeonia L. на базі архітектурно-експозиційної ділянки Ботанічного саду "Поділля" BHAУ

На рис. 1 введено такі позначення: 1 - "China Maid", 2 - "Чарівник", 3 - "Heritage", 4 - "Triumphe du Nord", 5 - "Корифей", 6 - "Малинова ватра", 7 - "Антей", 8 "Mahogany", 9 - "Diana Parks", 10 - "Cherry Red", 11 "Venus", 12 - "Сара Бернар", 13 - "Reine Hortense", 14 "Червоні вітрила", 15 - "Світоч", 16 - "Ліхтарик", 17 "Жемчужна розсип", 18 - "Henry Bockstoce", 19 "Mons. Jules Elie", 20 - "Seraphim", 21 - "Червоний оксамит", 22 - "Rubra plena", 23 - "Tenifolia plena", 24 "Тонколистий степовий", 25 - "Doreen", 25 - "Gay Paree", 27 - "Gold Standart", 28 - "Hit Parade", 29 - "Moon of Nippon", 30 - "Neon" , 31 - "Philomele", 32 - "Hot Chocolate".

Для вивчення особливостей цвітіння використовували методику А. Н. Пономарьова. Для спостереження за добовою ритмікою цвітіння етикетували певну кількість особин і кожні дві години підраховували квітки, що розкрились. Визначали також тривалість цвітіння окремого суцвіття. За відомою методикою I. Ф. Сациперової вивчали особливості онтогенезу, що потрібно застосовувати для поглибленого вивчення рослин. Для визначення економічної ефективності виробництва садивного матеріалу культури півонії здійснили розрахунок собівартості, порядок якого регулює Положення (стандарт) бухгалтерського обліку "Витрати", а також "Методика визначення економічної ефективності витрат на наукові дослідження і розробки та їх впровадження у виробництво".

Результати дослідження та їх обговорення. Встановлено, що усі досліджувані культивари належать до груп 3 дуже раннім, раннім, ранньо-середнім, середнім, середньопізнім та пізнім строками цвітіння. Наявні квіти як зі слабким, так і з сильним ароматом. Використовуються для букетів, квітників, моносадів, флористичних композицій та як лікарські рослини. Забарвлення квітів змінюється від білого до темно-червоного. Форма - від простої немахрової до махрової [9]. За результатами досліджень визначено основні морфометричні показники видів та сортів Paeonia L. (табл. 1).

Встановлено, що в досліджуваних умовах розмір квітки змінюється від 10 до 20 см. Так, найбільший розмір квітки зафіксовано на ділянках сортів і гібридів пі- 
воній "China Maid", "Корифей", "Cherry Red", "Сара Бернар", "Henry Bockstoce" та "Mons. Jules Elie". Найменший розмір квітки - у культиварів "Tenifolia plena" та "Тонколистий степовий".

Примірники півонії, які представлені на архітектурно-експозиційній ділянці ВНАУ, можуть забезпечити безперервне та інтенсивне цвітіння, оскільки належать до різних груп (табл. 2).

Встановлено, що спектр цвітіння досліджуваних видів півоній складається з білого, різних відтінків черво- ного, рожевого, що створює насичену кольорову гаму, що представляє собою високу декоративність та перспективність для вирощування в умовах архітектурноекспозиційної ділянки ВНАУ.

Унаслідок узагальнених рекомендацій створено проекти двох клумб для облаштування пакової зони Вінницького національного аграрного університету, які також можуть використовуватися як елементи ландшафтного дизайну приватних будинків, так і громадських організацій, парків та скверів (рис. 2).

Табл. 1. Морфометричні показники, забарвлення квітки та строки цвітіння декоративно цінних сортів Paeоnia L.

\begin{tabular}{|c|c|c|c|c|c|c|c|}
\hline $\begin{array}{l}\text { № } \\
\text { 3/ח }\end{array}$ & Сорт (гібрид) & Форма квітки & $\begin{array}{c}\text { Термін } \\
\text { цвітіння }\end{array}$ & $\begin{array}{l}\text { Розмір } \\
\text { квітки }\end{array}$ & $\begin{array}{c}\text { Наявність } \\
\text { аромату }\end{array}$ & $\begin{array}{c}\text { Забарвлення } \\
\text { квітки }\end{array}$ & Використання \\
\hline 1 & "China Maid" & Японська & $\begin{array}{l}\text { Середньо- } \\
\text { пізній }\end{array}$ & 20 & Ароматний & Світло-рожевий & Флористичні композиції \\
\hline 2 & "Чарівник" & Махрова шаровидна & Середній & 18 & Аромат конвалії & Білий & Моносади \\
\hline 3 & "Heritage" & Махрова & Ранній & 18 & Ароматний & Червоний & Солітери, міксбордери \\
\hline 4 & $\begin{array}{l}\text { "Triumphe du } \\
\text { Nord" }\end{array}$ & Махрова & Пізній & 18 & Ароматний & Рожевий & Флористичні композиції \\
\hline 5 & "Корифей" & Махрова & Ранній & 20 & Слабкий & Червоний & Міксбордер \\
\hline 6 & $\begin{array}{c}\text { "Малинова } \\
\text { ватра" }\end{array}$ & Махрова & Середній & 18 & Ароматний & Кармінно-червоний & Фон міксбордерів \\
\hline 7 & "Антей" & Махрова розовидна & Середній & 16 & Слабкий & Малиново-червоне & Група, масив \\
\hline 8 & "Mahogany" & Проста & $\begin{array}{c}\text { Ранньо-се- } \\
\text { редній }\end{array}$ & 18 & Ароматний & Червоний & Група, масив \\
\hline 9 & "Diana Parks" & Махрова розовидна & $\begin{array}{c}\text { Ранньо-се- } \\
\text { редній }\end{array}$ & 14 & Ароматний & Криваво-червоний & Міксбордер, рабатка \\
\hline 10 & "Cherry Red" & Махрова розовидна & Ранній & 20 & Ароматний & Червоний & Солітер \\
\hline 11 & "Venus" & Махрова корончаста & Середній & 18 & Слабкий & Рожевий & Солітер, міксбордер \\
\hline 12 & "Сара Бернар" & Напів-махрова & $\begin{array}{c}\text { Середньо- } \\
\text { пізній }\end{array}$ & 20 & Сильний & Світло-рожевий & $\begin{array}{c}\text { Солітер, флористичні } \\
\text { композиції }\end{array}$ \\
\hline 13 & "Reine Hortense" & Махрова & Середній & 17 & Слабкий & Рожевий & Флористичні композиції \\
\hline 14 & $\begin{array}{l}\text { "Червоні } \\
\text { вітрила" }\end{array}$ & Проста & $\begin{array}{c}\text { Ранньо-се- } \\
\text { редній }\end{array}$ & 15 & Слабкий & Червоний & Флористичні композиції \\
\hline 15 & "Світоч" & Махрова & $\begin{array}{c}\text { Середньо- } \\
\text { пізній }\end{array}$ & 16 & Слабкий & Червоний, рожевий & Міксбордер \\
\hline 16 & "Ліхтарик" & Махровий & Ранній & 17 & Слабкий & $\begin{array}{c}\text { Малиново-черво- } \\
\text { ний } \\
\end{array}$ & Міксбордер \\
\hline 17 & $\begin{array}{l}\text { "Жемчужна } \\
\text { розсип" }\end{array}$ & Японська & Ранній & 16 & Ароматний & Рожевий & Група, масив \\
\hline 18 & $\begin{array}{c}\text { "Henry } \\
\text { Bockstoce" }\end{array}$ & Махрова & $\begin{array}{c}\text { Ранньо-се- } \\
\text { редній }\end{array}$ & 20 & Слабкий & Криваво-червоний & Солітер \\
\hline 19 & $\begin{array}{l}\text { "Mons. Jules } \\
\text { Elie" }\end{array}$ & Махрова & Ранній & 20 & Ароматний & Рожевий & Солітери, групи, масиви \\
\hline 20 & "Seraphim" & Проста & $\begin{array}{l}\text { Дуже ран- } \\
\text { ній }\end{array}$ & 15 & Ароматний & Білий & Флористичні композиції \\
\hline 21 & $\begin{array}{l}\text { "Червоний } \\
\text { оксамит" }\end{array}$ & Напівмахрова & Ранній & 15 & Слабкий & Темно-червоний & Моносади \\
\hline 22 & "Rubra plena" & $\begin{array}{c}\text { Махрова } \\
\text { напівшаровидна }\end{array}$ & Ранній & 14 & Слабкий & Червоний & Солітер, міксбордер \\
\hline 23 & "Tenifolia plena" & Махрова & Ранній & 10 & Слабкий & Червоний & Рокарії, змішані клумби \\
\hline 24 & $\begin{array}{c}\text { "Тонколистий } \\
\text { степовий" }\end{array}$ & Немахрова & Ранній & 10 & Слабкий & Криваво-червоний & Рокарії, змішані клумби \\
\hline 25 & "Doreen" & Японська & Середній & 16 & Ароматний & $\begin{array}{l}\text { Рожевий, стаміно- } \\
\text { дії жовті }\end{array}$ & Солітер \\
\hline 26 & "Gay Paree" & Японська & $\begin{array}{c}\text { Середньо- } \\
\text { пізній }\end{array}$ & 13 & Ароматний & Рожевий & Солітер \\
\hline 27 & "Gold Standart" & Японська & Середній & 15 & Слабкий & Білий & $\begin{array}{c}\text { Клумби безперервного } \\
\text { цвітіння } \\
\end{array}$ \\
\hline 28 & "Hit Parade" & Японська & Середній & 14 & Ароматний & Рожевий & $\begin{array}{l}\text { Міксбордери, масиви, } \\
\text { групи }\end{array}$ \\
\hline 29 & $\begin{array}{l}\text { "Moon of } \\
\text { Nippon" }\end{array}$ & Японська & $\begin{array}{c}\text { Середньо- } \\
\text { пізній }\end{array}$ & 16 & Ароматний & Біло-салатовий & Міксбордер, моносади \\
\hline 30 & "Neon" & Японська & Пізній & 16 & Ароматний & Рожевий & Міксбордер \\
\hline 31 & "Philomele" & Японська & Ранній & 12 & Слабкий & Рожевий & Міксбордер \\
\hline 32 & "Hot Chocolate" & Японська & Середній & 16 & Ароматний & Темно-червоний & Групи, масиви \\
\hline
\end{tabular}


Табл. 2. Спектр цвітіння півоній, представлених на архітектурно-експозиційній ділянці ВНАУ

\begin{tabular}{|c|c|c|c|c|c|c|c|c|c|c|}
\hline \multirow{3}{*}{$\begin{array}{l}\text { № } \\
\text { 3/ח }\end{array}$} & \multirow{3}{*}{ Назва сорту/гібриду } & \multicolumn{9}{|c|}{ Місяць / декада } \\
\hline & & \multicolumn{3}{|c|}{ травень } & \multicolumn{3}{|c|}{ червень } & \multicolumn{3}{|c|}{ липень } \\
\hline & & 1 & 2 & 3 & 1 & 2 & 3 & 1 & 2 & 3 \\
\hline 1 & "China Maid" & & & & \multicolumn{3}{|c|}{ Світло-рожевий } & & & \\
\hline 2 & "Чарівник" & & & & \multicolumn{2}{|c|}{ Білий } & & & & \\
\hline 3 & "Heritage" & & & Червоний & & & & & & \\
\hline 4 & "Triumphe du Nord" & & & & & & & & & \\
\hline 5 & "Корифей" & & & \multicolumn{2}{|c|}{ Червоний } & & & & & \\
\hline 6 & "Малинова ватра" & & & \multicolumn{2}{|c|}{ Кармінно-червоний } & & & & & \\
\hline 7 & "Антей" & & & & & \multicolumn{3}{|c|}{ Малиново-червоне } & & \\
\hline 8 & "Mahogany" & & & & Червоний & & & & & \\
\hline 9 & "Diana Parks" & & & & $\begin{array}{l}\text { Криваво- } \\
\text { червоний }\end{array}$ & & & & & \\
\hline 10 & "Cherry Red" & & & Червоний & & & & & & \\
\hline 11 & "Venus" & & & & & Рожевий & & & & \\
\hline 12 & "Сара Бернар" & & & & & \multicolumn{3}{|c|}{ Світло-рожевий } & & \\
\hline 13 & "Reine Hortense" & & & & & \multicolumn{2}{|c|}{ Рожевий } & & & \\
\hline 14 & "Червоні вітрила" & & & & & & & \multicolumn{2}{|c|}{ Червоний } & \\
\hline 15 & "Світоч" & & & \multicolumn{2}{|c|}{ Червоний, рожевий } & & & & & \\
\hline 16 & "Ліхтарик" & & & $\begin{array}{c}\text { Малиново- } \\
\text { червоний }\end{array}$ & & & & & & \\
\hline 17 & "Жемчужна розсип" & & & & & Рожевий & & & & \\
\hline 18 & "Henry Bockstoce" & & & & & \multicolumn{4}{|c|}{ Криваво-червоний } & \\
\hline 19 & "Mons. Jules Elie" & & & & & & \multicolumn{2}{|c|}{ Рожевий } & & \\
\hline 20 & "Seraphim" & & & Білий & & & & & & \\
\hline 21 & "Червоний оксамит" & & & & & $\begin{array}{c}\text { Темно- } \\
\text { червоний }\end{array}$ & & & & \\
\hline 22 & "Rubra plena" & & & \multicolumn{3}{|c|}{ Червоний } & & & & \\
\hline 23 & "Tenifolia plena" & \multicolumn{2}{|c|}{ Червоний } & & & & & & & \\
\hline 24 & "Тонколистий степовий" & \multicolumn{2}{|c|}{ Криваво-червоний } & & & & & & & \\
\hline 25 & "Doreen" & & & & & \multicolumn{3}{|c|}{ Рожевий, стамінодії жовті } & & \\
\hline 26 & "Gay Paree" & & & & & \multicolumn{2}{|c|}{ Рожевий } & & & \\
\hline 27 & "Gold Standart" & & & & & Білий & & & & \\
\hline 28 & "Hit Parade" & & & & & Рожевий & & & & \\
\hline 29 & "Moon of Nippon" & & & & & \multicolumn{2}{|c|}{ Біло-салатовий } & & & \\
\hline 30 & "Neon" & & & & & & \multicolumn{2}{|c|}{ Рожевий } & & \\
\hline 31 & "Philomele" & & & \multicolumn{2}{|c|}{ Рожевий } & & & & & \\
\hline 32 & "Hot Chocolate" & & & & & \multicolumn{2}{|c|}{ Темно-червоний } & & & \\
\hline
\end{tabular}
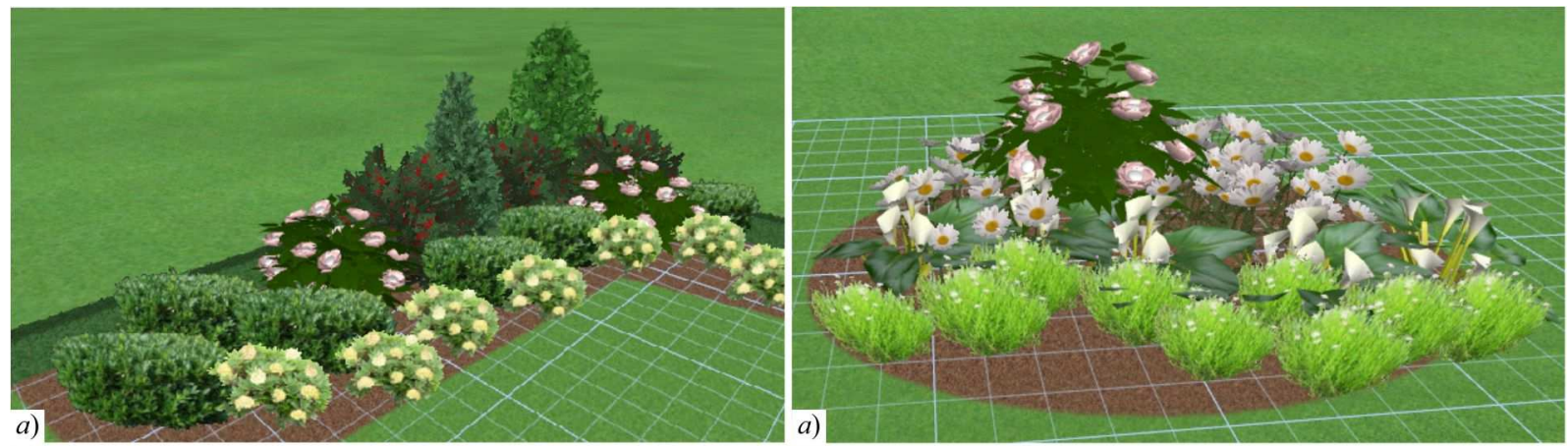

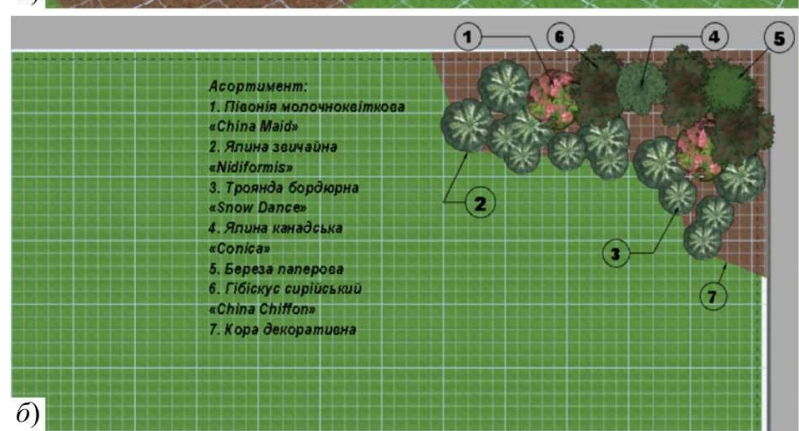

Клумба № 1

Рис. 2. Проекти клумб: a) перспектива; б) план

Представники Paeonia L. не варто висаджувати на передньому плані клумби щільною стіною, а також їх не потрібно підбивати дрібними квітами, стриженим

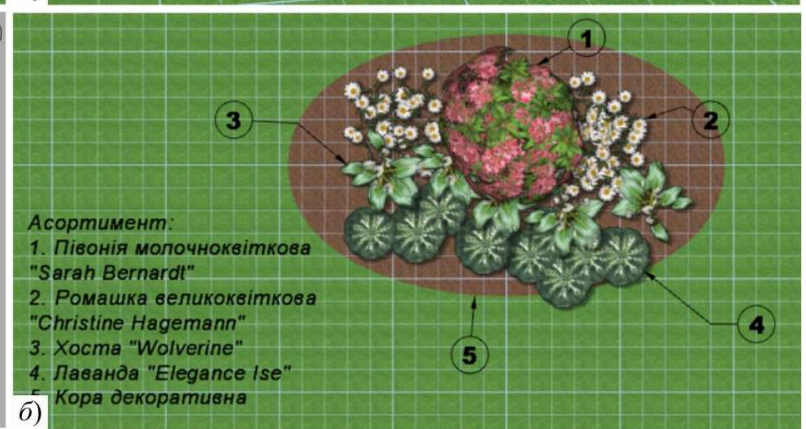

Клумба № 2

бордюром і облямівкою. Півонії чудово виглядають у паркових галявинах, особливо на ділянках безперервного цвітіння. Але треба враховувати, що вони є садовими 
квітами і групування необхідно підбирати відповідне. Не допускається поєднання півоній з "дикими" рослинами, включати його в ландшафтну групу, що копіює ліс, гай, гірський куточок.

Результати виконаних досліджень, під час яких проводили спостереження за рослинами роду Paeonia L., мають як наукове, так і практичне значення. Ми провели економічну оцінку ефективності вирощування рослин на архітектурно-експозиційній ділянці ВНАУ та розрахували загальну собівартість здійснених проектів квітників з використанням півоній станом на 2019 р.

Висока ціна на цю продукцію забезпечує високу рентабельність, проте ефективність іiі реалізації буде помітна лише через декілька років, коли півонії сформують потужне кореневище та почнуть рясно цвісти. Визначивши перспективність вирощування півоній та розробивши проекти клумб з використанням Paeonia L. розроблено кошторис цих композицій, який подано у табл. 3 та 4. Загальна собівартість запроектованої клумби № 1 за цінами 2019 р. становить 1270 грн, з них 8 \% становить вартість рослин півонії.

Табл. 3. Виробничі витрати на рослинний та допоміжний матеріал для проекту квітника № 1

\begin{tabular}{|c|c|c|c|c|}
\hline № & $\begin{array}{c}\text { Назва рослинного матеріалу } \\
\text { та допоміжних елементів }\end{array}$ & $\begin{array}{c}\text { Кіль- } \\
\text { кість, шт. }\end{array}$ & $\begin{array}{c}\text { Ціна за } \\
\text { одницю, } \\
\text { грн }\end{array}$ & $\begin{array}{c}\text { Вар- } \\
\text { тість, } \\
\text { грн }\end{array}$ \\
\hline 1 & $\begin{array}{c}\text { Півонія молочноквіткова } \\
\text { "Sarah Bernardt" }\end{array}$ & 1 & 100 & 100 \\
\hline 2 & $\begin{array}{c}\text { Ромашка великоквіткова } \\
\text { "Сhristine Hagemann }\end{array}$ & 3 & 45 & 135 \\
\hline 3 & Хоста "Wolverine" & 5 & 47 & 235 \\
\hline 4 & Лаванда "Munstead" & 9 & 65 & 585 \\
\hline 5 & Кора декоративна & $\begin{array}{c}9 \text { мішків } \\
\times 50 \text { л }\end{array}$ & 50 & 450 \\
\hline \multicolumn{4}{|c|}{ Всього: } \\
\hline
\end{tabular}

Табл. 4. Виробничі витрати на рослинний та допоміжний матеріал для проекту квітника № 2

\begin{tabular}{|c|c|c|c|c|}
\hline $\begin{array}{l}\text { № } \\
\Pi / \Pi\end{array}$ & $\begin{array}{c}\text { Назва рослинного } \\
\text { матеріалу та допоміжних } \\
\text { елементів } \\
\end{array}$ & $\begin{array}{c}\text { Кількість, } \\
\text { шт. }\end{array}$ & $\begin{array}{l}\text { Ціна за } \\
\text { одини- } \\
\text { цю, грн } \\
\end{array}$ & $\begin{array}{c}\text { Bap- } \\
\text { тість, } \\
\text { грн }\end{array}$ \\
\hline 1 & $\begin{array}{l}\text { Півонія молочноквіткова } \\
\text { "China Maid" }\end{array}$ & 2 & 300 & 600 \\
\hline 2 & $\begin{array}{c}\text { Ялина звичайна } \\
\text { "Nidiformis" }\end{array}$ & 6 & 890 & 5340 \\
\hline 3 & $\begin{array}{l}\text { Троянда бордюрна } \\
\text { "Snow Dance" }\end{array}$ & 7 & 65 & 455 \\
\hline 4 & Ялина канадська "Conica" & 1 & 1685 & 1685 \\
\hline 5 & Береза паперова & 1 & 124 & 124 \\
\hline 6 & $\begin{array}{l}\text { Гібіскус сирійський } \\
\text { "China Chiffon" }\end{array}$ & 3 & 130 & 390 \\
\hline 7 & Кора декоративна & $\begin{array}{l}15 \text { мішків } \\
\times 50 \text { л }\end{array}$ & 50 & 750 \\
\hline \multicolumn{4}{|c|}{ Всього: } & 9344 \\
\hline
\end{tabular}

Собівартість клумби № 2 - 9344 грн, 3 них $7 \%$ вартість використаних рослин півоній. За результатами досліджень встановлено, що вирощування досліджуваних видів роду Paeonia L. є економічно доцільним. Лікарські властивості півонії, про які $є$ вже у давньогрецькому міфі про тї походження, відомі у Свропі здавна давньоримський філософ I ст. до н.е. Пліній Старший нараховував $з$ два десятки захворювань, які лікують за допомогою корневища півонії лікарської (Paeonia officinalis).

Природні властивості півоній характеризують ці рослини як багате за якісними показниками джерело для збільшення асортименту декоративних культур відкритого і закритого грунту в умовах Ботанічного саду "Поділля" Вінницького національного аграрного університету. Ціна залежить від ситуації на ринку, перспективності та популярності посадкового матеріалу.

Нагадаємо, що найширше застосування півонії знаходять як декоративні квіти, тобто їх використовують в озелененні, для зрізування та зимової вигонки. Здавна відомі також лікарські властивості півоній, позаяк люди здавна ії культивують. Сьогодні відомі сотні сортів цих квітів, як розрізняють розмірами і формами, забарвленням, будовою квітів, тривалістю цвітіння тощо.

Півонії віддають перевагу добре освітленим і прогрітим сонцем ділянкам, також стійкі до легкого затінку. Для висадки півонії посадкову яму треба підготувати заздалегідь - на дно викладають дренаж з битої цегли або крупного гравію, засипають 20-25 кг органічних добрив, які ретельно перемішують з землею, далі поливають яму і за потреби додають грунт. Оптимальний термін висадки півоній - серпень-вересень. Розмноження півоній зазвичай здійснюють за допомогою кущів, але також відростками коріння і стеблин.

Висновки. Унаслідок проведених експериментальних досліджень виявлено, що 32 сорти/гібриди півоній придатні для вирощування на базі архітектурно-експозиційної ділянки Ботанічного саду "Поділля" Вінницького національного аграрного університету. Усі представники різняться між собою за формою квітки, терміном цвітіння та розміром квітки, інтенсивністю аромату, проте усі вони ідеально підходять для використання у ландшафтному дизайні та озеленення.

\section{References}

1. Herbaceous Peonies. American Peony Society: veb-sait. (2019). Retrieved from: https://americanpeonysociety.org/learn/herbaceo us-peonies/

2. Horobets, V. F., Mashkovska, S. P., Buidin, Yu. V., et al. (2008). Kolektsiinyi fond kvitnykovo-dekoratyvnykh roslyn Natsionalnoho botanichnoho sadu im. M. M. Hryshka NAN Ukrainy: kataloh roslyn. Ternopil: Medobory, 180 p. [In Ukrainian].

3. Kataloh sortiv roslyn, prydatnykh dlia poshyrennia v Ukraini na 2018 rik: vytiah. (2018). 400 p. [In Ukrainian].

4. Leshcheniuk, E. M., Linckevych, O. O., \& Chipilyak, T. F. (2018). Perspektyvy vykorystannia sortu pivonii travianoi dlia ozelenennia v umovakh pravoberezhnoho stepovoho Prydniprovia. Scientific Bulletin of UNFU, 28(7), 36-39. https://doi.org/10.15421/40280707

5. Mazur, V. A., Pantsyreva, H. V., Mazur, K. V., \& Monarkh, V. V. (2019). Ecological and biological evaluation of varietal resources Paeonia L. in Ukraine. Acta Biologica Sibirica, 5(1), 141-146. https://doi.org/10.14258/abs.v5.i1.5350

6. Mazur, V. A., Prokopchuk, V. M., \& Pantsyreva, H. V. (2018). Perspektyvnist stvorennia kolektsii pivonii na bazi botanichnoho sadu "Podillia" Vinnytskoho natsionalnoho ahrarnoho universytetu. Silske hospodarstvo i lisivnytstvo. Vinnytsia: VNAU, 14 p. [In Ukrainian].

7. Mazur, V. A., Prokopchuk, V. M., \& Pantsyreva, H. V. (2018). Pervynne introduktsiine otsiniuvannia dekoratyvnykh vydiv rodu Lupinus v umovakh Podillia. Scientific Bulletin of UNFU, 28(7), 40-43. https://doi.org/10.15421/40280708

8. Melnychuk, N. Y., \& Henyk, Y. V. (2019). Topoklimatychni osoblyvosti sadovo-parkovykh kompozytsiinykh hrup u parkakh mista Lvova. Scientific Bulletin of UNFU, 29(7), 108-111. https://doi.org/10.15421/40290721

9. Pantsyreva, H. V. (2018). Doslidzhennia sortovykh resursiv travianykh vydiv Paeonia L. v Ukraini. Scientific Bulletin of UNFU, 28(8), 74-78. https://doi.org/10.15421/40280815 
10. Pantsyreva, H. V., Mykoliuk, O. O., \& Semchuk, V. V. (2019). Suchasnyi stan kolektsii pivonii na bazi botanichnoho sadu "Podillia" Vinnytskoho natsionalnoho ahrarnoho universytetu. Scientific Bulletin of UNFU, 29(8), 46-50. https://doi.org/10.36930/40290806
11. Piet Oudolf Designing with plants. (1999). Portlend: Timber Press, $152 \mathrm{p}$.

12. Sydoruk, T. M. (2007). Travianysti bahatorichni roslyny vidkrytoho gruntu Natsionalnoho dendroparku "Sofiivka", (pp. 115-122). Uman: UVPP. [In Ukrainian].

V. M. Procopchuk, I. M. Didur, H. V. Pantsyreva

Vinnytsia National Agrarian University, Vinnytsia, Ukraine

\section{THE PROSPECTS OF USE PAEONIA L. IN THE BOTANICAL GARDEN "PODILLYA" VINNYTSIA NATIONAL AGRARIAN UNIVERSITY}

The results of the study of the prospects of cultivation of 32 cultivars of Paeonia $\mathrm{L}$. in the conditions of the Botanical Garden "Podillya" of Vinnytsia National Agrarian University are highlighted. A literary analysis of scientific sources is presented, comparing the world experience of growing peonies and their use in landscape design. The systematized and generalized information about the cultivation characteristics of varieties and hybrids of world and Ukrainian breeding are presented, the most promising specimens for cultivation on the basis of the Botanical Garden "Podillya" of the VNAU are determined. The economic evaluation of the prospects of cultivation of varieties and hybrids of Paeonia L. on the architectural-exposition plot of the VNAU. In the course of the research, the relevance of using Paeonia L. surveyed representatives for landscaping of cities, towns and private homes was determined in order to improve the aesthetic perception of the projected objects. The economic feasibility of growing these flora representatives was analyzed in order to further sell the products on the market and the directions for the use of peonies were determined. It is established that the investigated varieties/hybrids are of interest as potentially valuable objects for replenishing the range of domestic ornamental plants and are promising for the improvement of the condition of parks, squares, gardens of the Podillya area. Considering the high decorative qualities of these species and the wide possibilities of their application, flower and ornamental plants of representatives of herbaceous species of Paeonia L. are of great interest for landscaping, in particular floriculture and for replenishing the range of decorative crops of our state. The research also identified the natural possibilities of representatives of herbaceous species of Paeonia L., plasticity to change their life form, high quality on the set of characteristics that determine their ornamental characterizes the studied plants, as a source for introduction, as well as the enrichment of the range of ornamental crops in Ukraine. Thus, the study of representatives of the genus Paeonia L. for landscaping will greatly expand the range of ornamental plants and enrich the cultivated flora of the Podillia and Ukraine as a whole. Comparison of the results obtained with the characteristics of the varieties presented by the originator showed the coincidence of varietal characteristics in all indicators. The research results will be used to replenish the existing collection of peonies on the basis of the Botanical Garden "Podillya" of VNAU and the practical activities of students of the specialty 206 "Landscape gardening" and scientists.

Keywords: Paeonia L.; cultivar; use cases; cultivation area; project; economic efficiency. 